\title{
The Fiduciary Duties of Corporate Directors to "Phantom" Stockholders
}

\author{
D. Kyle Sampson $\dagger$
}

Companies seeking to attract or retain key employees often implement "phantom" stock plans. These plans confer on selected employees the financial benefits of stock ownership without granting them an equity interest in the company or requiring them to make a corresponding capital investment. ${ }^{1}$ Under phantom stock plans, companies credit selected employees with a specified number of "shares" of company stock, and then contractually promise the employees that they will receive the value of those shares at a future date. ${ }^{2}$ Consequently, employees with phantom stock accumulate wealth through the continuing success of the company, and employers are able to encourage employees to remain with the firm. ${ }^{3}$

The increased use of phantom stock plans has given rise to questions concerning the nature of the relationship between the company managers who implement the plans and the employees who receive the phantom stock. In general, corporate directors must behave appropriately toward the persons to whom they owe fiduciary duties. ${ }^{4}$ But as Justice Frankfurter said, "to say that a man is a fiduciary only begins analysis; it gives direction to fur-

\footnotetext{
$\dagger$ B.A. 1993, Brigham Young University; J.D. Candidate 1996, The University of Chicago.

1 See Mark A Teitelbaum, Insurance-Funded Incentive Compensation: Phantom Stock and Stock Appreciation Rights, J Am Society CLU \& ChFC 44, 46 (July 1994); Robert Charles Clark, Corporate Law $\$ 6.2 .1$ at 208 (Little, Brown, 1986) (shareholder rights to vote, inspect, and sue derivatively that derive from the equity relationship are not held by phantom stockholders). Compare Peter W. Hutchings, The Phantom Stock Plan, J Am Society CLU 34, 34 (Jan 1986) (noting both that holders of phantom stock do not acquire ownership interests in the company and that holders of phantom stock receive the benefits of equity in the company). This Comment ultimately takes the position that phantom stockholders are not equity holders.

2 Hutchings, J Am Society CLU at 34.

3 Id.

- Fiduciary duties are among the highest duties the law can impose. See John C. Carter, The Fiduciary Rights of Shareholders, 29 Wm \& Mary L Rev 823, 824-31 (1988). See also Meinhard v Salmon, 249 NY 458, 164 NE 545, 546 (1928). Although Meinhard concerned a partnership, Chief Judge Cardozo wrote that the fiduciary duty of "undivided loyalty is relentless and supreme..., and his opinion is often cited to describe the fiduciary relationship between parties in a corporation. Id at 548 .
} 
ther inquiry. To whom is he a fiduciary? What obligations does he owe as a fiduciary?"5 Directors do owe fiduciary duties to common shareholders, the actual owners of the assets that the directors manage. As fiduciaries, directors must act for the benefit of the corporation and the shareholders, and subordinate their personal interests. ${ }^{6}$ In contrast, corporate directors generally do not owe fiduciary duties to creditors, so long as the corporation is solvent. ${ }^{7}$ Where phantom stockholders fit within this scheme is uncertain. Thus, phantom stock plans present a novel question under corporate law: Are phantom stockholders like holders of common stock, or are they merely debt holders? The answer to this question determines whether corporate officers and directors owe fiduciary duties to phantom stockholders.

This Comment analyzes the legal characteristics of phantom stock and argues that, despite the "unprecedented expansion" of fiduciary law, ${ }^{8}$ corporate directors should not owe fiduciary duties to phantom stockholders. Section I describes the common features of phantom stock plans and explains their advantages and disadvantages for both employers and employees. It also discusses the strong parallels between phantom stock and nonvoting common stock, which does carry fiduciary duties. Section II briefly compares the fiduciary duties directors owe to common stockholders with the duties they owe to creditors, and outlines the reasons why some groups are protected by fiduciary duties while others are not. Finally, Section III concludes that it is precisely because phantom stock and nonvoting common stock are so similar that the fiduciary duties of corporate directors should not extend to phantom stockholders. Rather, employees and employers should be permitted to bargain freely for fiduciary duties by electing one or the other of these stockholder options. Section III thus examines the justifications for allowing parties to bargain freely, points out problems that would arise if directors did owe fiduciary duties to phantom stockholders, and rebuts the argument that phantom stockholders are like minority shareholders in close corporations, who do receive fiduciary protections.

- SEC v Chenery Corp., 318 US 80, 85-86 (1943).

- Beth A. Buday and Gail A. O'Gradney, 3 Fletcher Cyclopedia of the Law of Private Corporations $\$ 837.50$ at 181-83 (Clark Boardman Callaghan, perm ed 1994).

7 See, for example, In re STN Enterprises, 779 F2d 901, 904 (2d Cir 1985). See also Geyer v Ingersoll Publications Co., 621 A2d 784, 787 (Del Chanc 1992).

${ }^{8}$ See Tamar Frankel, Fiduciary Law, 71 Cal L Rev 795, 796 (1983). 


\section{Phantom STOCK}

As employers have turned increasingly toward incentivebased payment programs, ${ }^{9}$ phantom stock has become more popular as an alternative form of deferred compensation. ${ }^{10}$ Although large, publicly held corporations use phantom stock plans, the plans are most common among closely held companies, which often find it impractical to issue shares of real stock for incentive plan purposes. ${ }^{11}$

\section{A. Description and Common Features}

Phantom stock plans vary; thus, the term "phantom stock" may be used to describe any form of long-term employee incentive arrangement using units of compensation equivalent to actual shares of the employer's stock. ${ }^{12}$ Nevertheless, all phantom stockholder agreements have many common features and are similar in structure to nonvoting stockholder agreements.

\section{Plan mechanics.}

Under a phantom stock plan, an employer establishes a phantom stock account for an employee and grants fictional shares of company "stock" to him. ${ }^{13}$ Because actual shares are not transferred, the stock exists only as a bookkeeping entry and is therefore appropriately called "phantom" (or "shadow") stock. ${ }^{14}$ Most phantom stock arrangements are structured so that an employee receives a specified number of vested shares for each year that he is employed by the corporation. ${ }^{15}$ Through the contract the company promises the employee that he will receive the value of the vested shares at a specified future date ${ }^{16}$-usually retirement, ${ }^{17}$ termination of employment, or some other

9 See Lee Berton, This Year's Model: Don't like the salary? Just change the formula, Wall St J R5 (Apr 17, 1991) (reproducing a survey regarding the popular forms of employee compensation).

10 Teitelbaum, J Am Society CLU \& ChFC at 44 (cited in note 1).

1 Subcommittee on Executive Compensation of the Committee on Employee Benefits and Executive Compensation of the American Bar Association, Executive Compensation: $A$ 1987 Road Map for the Corporate Advisor, 43 Bus Law 185, 320 (1987).

12 Id at 319.

13 See Hutchings, J Am Society CLU at 34 (cited in note 1). See also Note, Phantom Stock Plans, 76 Harv L Rev 619, 619-20 (1963).

14 Hutchings, J Am Society CLU at 34 (cited in note 1).

1s See id.

16 See id.

17 At least one court has recognized that the Employee Retirement Income Security 
agreed-upon date. ${ }^{18}$

Many phantom stock plans attempt to replicate the actual ownership rights of common stockholders by basing the value of the deferred compensation on the underlying value of the company's common stock, and by paying the same dividends to phantom stockholders as are paid to regular common stockholders. The employer either pays these dividends directly to the employee or credits their equivalent value to the employee's phantom stock account. ${ }^{19}$

Employees entering into phantom stockholder agreements usually want to know how their account will be valued. This information enables employees who consider leaving the company for other employment to assess the worth of their accounts prior to departing. For this reason, most phantom stock plans provide a simple method for determining the value of the stock held in an employee's account..$^{20}$ In publicly held corporations, the value of an employee's phantom stock can easily be determined by multiplying the number of phantom shares in the employee's account by the market price of the shares on the day the account is settled. In closely held corporations, the most common method of valuing employee-owned phantom stock is to assess the net worth or book value of the corporation according to its balance sheet. ${ }^{21}$ Once the value of the corporation has been established, the value of the employee's phantom stock is usually determined by dividing the book value by the total number of shares outstanding (including the number of phantom shares), and then multiplying that number (the value per share) by the number of phantom shares held by the employee. ${ }^{22}$ When the employee

Act of 1974, 29 USC $\S 301$ et seq (1988 \& Supp 1993) ("ERISA"), may govern phantom stock plans. See Spitz $v$ Berlin Industries, Inc., 1994 US Dist LEXIS 1576, $* 15$ (N D III) (holding that phantom stock plan was covered by ERISA). Whether a particular phantom stock plan falls within the scope of ERISA, however, may be a question of fact to be determined at trial. See, for example, Strzelecki v Schwarz Paper Co., 824 F Supp 821, 827 (N D Il 1993). Plans that ERISA covers must have a "named fiduciary" who has ultimate responsibility for the management and administration of the plan. ERISA $\S 402(a)(1), 29$ USC § 1102(a)(1).

${ }_{18}$ Subcommittee on Executive Compensation, 43 Bus Law at 319 (cited in note 11). In addition, some phantom stock plans allow participants to determine their own settlement dates, just as stock option participants may determine when to exercise stock options. Id.

${ }_{19}$ Teitelbaum, J Am Society CLU \& ChFC at 45 (cited in note 1).

${ }^{20}$ Hutchings, J Am Society CLU at 34 (cited in note 1).

21 See id at 35 .

${ }^{22}$ See, for example, Will $v$ United Chambers Administrators, Inc., 1987 US Dist LEXIS 8473,*4 (N D Wl) (describing a phantom stockholder agreement under which the "value of Employee's Stock Units shall be equal to $(x)$ the fair market value of Employer 
finally settles the account, the employer may pay the award either as a lump sum or in installments over a period of years. ${ }^{23}$

Consider a hypothetical phantom stockholder agreement between HighTech industries and one of its employees, Hannah. $^{24}$ HighTech, a relatively new start-up company, is a closely held, family-run corporation owned by the Harrison family. Although Hannah is not an officer or director, she participates significantly in the operation of the company, and her contributions are greatly valued by her superiors. Thus, in order to induce Hannah to remain with the company, HighTech offers Hannah a plan under which she will be credited with one thousand shares of HighTech "stock"-that is, one thousand shares of phantom stock equal in value to one thousand shares of the family-held common stock. Since there are currently three thousand shares of outstanding common stock held by the Harrisons, Hannah is essentially an "owner" of 25 percent of HighTech Industries. Based on HighTech's total worth of $\$ 400,000$, Hannah's 25 percent share is worth $\$ 100,000$.

Each year for the next ten years-so long as she remains with HighTech-one hundred shares will become vested in Hannah's account. After ten years, the one thousand phantom shares credited to her account will be 100 percent vested. The value of the shares will be determined by the net worth of the company at the time Hannah settles her phantom stock account. For example, if HighTech has a net worth of $\$ 1$ million when Hannah settles, the company will owe Hannah $\$ 250,000$, or $\$ 250$ per share. If Hannah leaves for other employment, however, she will be entitled only to the value of the shares that have become vested. ${ }^{25}$

as set forth in an appraisal ... divided by (y) the number of shares of Employer's Common Stock issued and outstanding on the Termination Date and then multiplied by (z) the number of Stock Units held by Employee on his Termination Date").

23 Subcommittee on Executive Compensation, 43 Bus Law at 319 (cited in note 11).

24 This fictional plan is modeled after the hypothetical phantom stock plan described in Hutchings, $\mathrm{J}$ Am Society CLU at 35-36 (cited in note 1 ).

25 The following table graphically depicts the phantom stock plan of HighTech Industries. The company's worth is assumed to grow steadily at 10 percent per year.

\begin{tabular}{|c|c|c|c|c|c|c|c|}
\hline Year & $\begin{array}{l}\text { No. of } \\
\text { Shares } \\
\text { Credited }\end{array}$ & $\begin{array}{l}\text { Annual } \\
\text { Vested } \\
\text { Shares }\end{array}$ & $\begin{array}{l}\text { Cumulative } \\
\text { Vested } \\
\text { Shares }\end{array}$ & $\begin{array}{l}\text { Worth of } \\
\text { Company at } \\
10 \% \text { Growth }\end{array}$ & $\begin{array}{l}\text { Price per } \\
\text { Share at } \\
10 \& \text { Growth }\end{array}$ & $\begin{array}{l}\text { Value of } \\
\text { Vested } \\
\text { Shares }\end{array}$ & $\begin{array}{l}\text { Value of } \\
\text { Vested and } \\
\text { Nonvested } \\
\text { Shares }\end{array}$ \\
\hline 1 & 1,000 & 100 & 100 & $\$ 400,000$ & $\$ 100$ & $\$ 10,000$ & $\$ 100,000$ \\
\hline 2 & & 100 & 200 & $\$ 440,000$ & $\$ 110$ & $\$ 22,000$ & $\$ 110,000$ \\
\hline 3 & & 100 & 300 & $\$ 484,000$ & $\$ 121$ & $\$ 36,300$ & $\$ 121,000$ \\
\hline
\end{tabular}


2. Comparison to nonvoting stock.

Phantom stock is very similar to nonvoting common stock. Corporations frequently issue nonvoting stock to key employees pursuant to a stockholder agreement and in connection with the performance of the employee's services. ${ }^{26}$ The nonvoting stockholder agreement may stipulate many things-as phantom stockholder agreements often do-including when the shares will vest, when the employee may cash out, and if and when dividends will be paid. As with phantom stock, employers may offer nonvoting common stock in order to recruit and retain key employees without giving up corporate control. ${ }^{27}$ Unlike phantom stockholders, however, holders of nonvoting common stock are clearly owed fiduciary duties. ${ }^{28}$

Because phantom stock and nonvoting common stock are so similar, and because holders of nonvoting stock do receive fiduciary duties, one might argue that fiduciary duties should extend to holders of phantom stock. In this view, phantom stock is essentially another class of traditional stock; and since phantom stock and nonvoting stock may serve the same purposes, holders

\begin{tabular}{|c|c|c|c|c|c|c|}
\hline 4 & 100 & 400 & $\$ 532,400$ & $\$ 133$ & $\$ 53,240$ & $\$ 133,100$ \\
\hline 5 & 100 & 500 & $\$ 585,640$ & $\$ 146$ & $\$ 73,205$ & $\$ 146,410$ \\
\hline 6 & 100 & 600 & $\$ 644,204$ & $\$ 161$ & $\$ 96,631$ & $\$ 161,051$ \\
\hline 7 & 100 & 700 & $\$ 708,624$ & $\$ 177$ & $\$ 124,009$ & $\$ 177,156$ \\
\hline 8 & 100 & 800 & $\$ 779,487$ & $\$ 195$ & $\$ 155,897$ & $\$ 194,872$ \\
\hline 9 & 100 & 900 & $\$ 857,436$ & $\$ 214$ & $\$ 192,923$ & $\$ 214,359$ \\
\hline 10 & 100 & 1,000 & $\$ 943,179$ & $\$ 236$ & $\$ 235,795$ & $\$ 235,795$ \\
\hline
\end{tabular}

${ }^{26}$ Nonvoting common stock is not a new phenomenon; its issuance was upheld as early as 1917. See General Investment Co. v Bethlehem Steel Corp., 87 NJ Eq 234, 100 A 347, 352, (Chanc 1917).

${ }_{27}$ Compare id, where the company issued nonvoting common stock in order to prevent old ownership and control patterns from being disturbed. See also Richard $M$. Buxbaum, The Internal Division of Powers in Corporate Governance, 73 Cal L Rev 1671, 1713-19 (1985) (discussing nonvoting common stock and corporate control).

${ }^{28}$ See Zahn v Transamerica Corp., 162 F2d 36, 43-46 (3d Cir 1947) (holding that directors owe fiduciary duties to all common stockholders, including holders of nonvoting, preferred stock). See also Harry G. Henn and John R. Alexander, Laws of Corporations and Other Business Enterprises $\S 240$ at 651-56 (West, 3d ed 1983). Although holders of nonvoting common stock are owed fiduciary duties, their lack of voting power may still leave them susceptible to management misbehavior or inefficiency. See Buxbaum, $73 \mathrm{Cal}$ L Rev at 1715. 
of phantom stock and nonvoting common stock should be treated similarly.

However, it is precisely because phantom stock and nonvoting common stock are so similar that courts should respect the decision by employers and employees to enter into either phantom stockholder or nonvoting stockholder agreements. In other words, employers and employees-not courts-should determine whether or not a fiduciary relationship exists. Employers seeking to avoid fiduciary duties can offer phantom stock to key employees, while employees desiring the protection of fiduciary duties can bargain for nonvoting common stock. ${ }^{29}$

\section{B. The Advantages and Disadvantages of Phantom Stock Plans}

Phantom stock plans offer many advantages to both employers and employees. Employers usually institute the plans because they want to increase their employees' economic stake in the business and to enable their employees to share in the company's growth..$^{30}$ Phantom stock plans are ideal for closely held corporations or family businesses (like HighTech Industries) that wish to compensate key employees without relinquishing either an equity interest or corporate control. ${ }^{31}$

Phantom stock plans also allow employers to provide incentive-based compensation without requiring a capital investment on the part of the employee. ${ }^{32}$ Additionally, phantom stockholder agreements that require the credited phantom shares to vest over

20 See Section III.A., discussing the ramifications of allowing parties to bargain freely for fiduciary duties.

30 See, for example, In re Marriage of Leisner, 219 Ill App 3d 752, 579 NE2d 1091, 1092 (1991) (describing a phantom stock plan established "to encourage and reward [employees] in a manner that will stimulate [their] active interest in the development and financial success of the Company and strengthen [their] desire to remain with the Company"); Pogostin v Rice, Civ Act No 6235, slip op at 2 ([Del] Ct Chanc, Aug 12, 1983), aff'd, 480 A2d 619 (Del 1984) (examining a phantom stock plan expressly intended to provide an incentive to key employees and to enable the corporation to retain and attract high quality personnel). See also Teitelbaum, J Am Society CLU \& ChFC at 46 (cited in note 1).

31 See Teitelbaum, J Am Society CLU \& ChFC at 46 (cited in note 1). Publicly held companies, which are generally unconcerned with relinquishing ownership, may also use phantom stock plans because they do not want to dilute existing shareholders' equity through the issuance of new shares of stock to employees. Subcommittee on Executive Compensation, 43 Bus Law at 320 (cited in note 11).

${ }_{32}$ See Clark, Corporate Law $\S 6.2 .1$ at 208-09 (cited in note 1) (phantom stock plans avoid the need for financing by individual employees); Hutchings, J Am Society CLU at 35 (cited in note 1) ("The employee obtains the primary benefit of ownership without ... outof-pocket cost."). See also Teitelbaum, J Am Society CLU \& ChFC at 46 (cited in note 1). 
time (like the HighTech Industries plan) provide a stronger economic tie to the company than stock options or grants of common stock in the business. ${ }^{33}$ Because an employee realizes the full value of the phantom stock arrangement only by remaining with the company, and because phantom stock is generally illiquid, ${ }^{34}$ the plan serves as a sort of "golden handcuffs," helping the employer retain key employees. ${ }^{35}$ Furthermore, in order to prevent employees from going to work for competitors, many phantom stock plans include "no competition" provisions that require employees to forfeit their phantom stock if the provision is breached. $^{36}$

Phantom stock plans are also flexible and simple. They are flexible because an employer can discriminate in choosing which of its employees will participate in the plan. Thus, phantom stock is usually issued to a key employee whom an employer specifically wants to compensate and keep. ${ }^{37}$ Phantom stock plans are simple because establishing the plan typically requires only a resolution of the directors and the execution of an agreement with the employee. ${ }^{38}$ In addition, phantom stock plans are appealing because companies are not required to make any cash

33 See Teitelbaum, J Am Society CLU \& ChFC at 46 (cited in note 1). For example, if Hannah wishes to realize the full value of the one thousand shares of phantom stock granted to her, she must remain at HighTech for ten years-until all one thousand shares vest. In contrast, an employee given actual shares of stock or stock options can sell them for full value immediately upon receipt.

${ }_{34}$ See id (phantom stock provides a stronger economic tie to the company than outright sales or grants of interest in the business which can be resold by the employee). See, for example, Smoyer $v$ Taxation Division Director, 4 NJ Tax 42, 50 (1982), aff'd, 95 NJ 139, 469 A2d 920 (1983) (holding that because phantom stock units are "not assignable, discountable or marketable," they are not subject to New Jersey state income tax until they vest). In this way, phantom stock is like the stock of close corporations, for which there also is generally no market.

${ }_{35}$ See, for example, Dower $v$ Mosser Industries, Inc., 648 F2d 183, 186-87 (3d Cir 1981) (noting that key employees were given phantom stock because retaining them was "vital to the future of the company"). See also Hutchings, J Am Society CLU at 34 (cited in note 1) ('The term 'golden handcuffs,' thus, is applied to any plan which generates sufficient appeal to retain" key employees.).

${ }^{36}$ "No competition" provisions are most commonly found in phantom stock agreements where the settled "stock" is paid out in installments. See, for example, Healy $v$ Rich Products Corp., 981 F2d 68, 70 (2d Cir 1992). Some plans prescribe that employees who leave the company must forfeit their phantom stock. See Foltz v U.S. News \& World Report, Inc., 663 F Supp 1494, 1508 (D DC 1987), aff'd, 865 F2d 364 (DC Cir 1989) ("The phantom stock shares ... were subject to forfeiture if the awardee left the Company before normal retirement."). See also Hutchings, J Am Society CLU at 37 (cited in note 1).

37 Teitelbaum, J Am Society CLU \& ChFC at 45 (cited in note 1).

38 Id at 46. 
outlay until an employee settles his account-a particular benefit for start-up companies.

Phantom stock plans do have disadvantages, however. First, all phantom stock arrangements are premised on the notion that an employee's phantom shares will become more valuable as the business becomes more successful. The underlying assumption is that the employee's individual efforts will increase the value of the company. ${ }^{39}$ Yet gearing the economic reward to the overall performance of the company-as opposed to the employee's individual performance or the performance of the employee's division-may have detrimental effects. If an employee is performing well but the company is not correspondingly increasing in value, the employee may become frustrated and cease to work as hard. On the other hand, an employee may perform poorly relative to the strength of the business, resulting in overcompensation for the employee. ${ }^{40}$ This difficulty might be mitigated, however, by tying the value of the employee's phantom shares to the business performance of the employee's particular division.

Additionally, determining the value of an employee's phantom account may be burdensome for closely held companies, whose shares are not traded daily on an exchange and whose value per share of phantom stock is thus not readily ascertainable. ${ }^{41}$ Furthermore, because employees are not required to invest their own capital, it is possible that they will have less incentive to remain with the company if it does not perform well. ${ }^{42}$ Employers, in contrast, might have to pay more than anticipated to employees if a particular plan exceeds expectations. ${ }^{43}$ Finally, employees may feel that illiquid phantom stock arrangements with fixed settlement dates are less advantageous than traditional stock options, which can be exercised at any time. ${ }^{44}$ Many

39 Hutchings, J Am Society CLU at 34 (cited in note 1).

43 Teitelbaum, J Am Society CLU \& ChFC at 46 (cited in note 1). In Berkwitz $v$ Humphrey, 163 F Supp 78 (N D Ohio 1958), a federal district court held a phantom stock plan invalid because of the lack of relationship between the value of the services rendered by the employee and the market value of the stock by which his award was measured. Subsequent cases have not followed this view. See, for example, Lieberman $v$ Becker, 155 A2d 596, 601 (Del 1959) (expressly refusing to accept the reasoning of Berkwitz).

41 Teitelbaum, J Am Society CLU \& ChFC at 46 (cited in note 1). The value of phantom stock may also be difficult to determine where a company's overall worth is disputed. See, for example, Foltz, 865 F2d at 367.

42 Teitelbaum, J Am Society CLU \& ChFC at 47 (cited in note 1).

43 Id.

44 See, for example, Spitz v Berlin Industries, Inc., 1994 US Dist LEXIS 1576, *1-2 (N D III) (describing a phantom stockholder agreement that was amended when employees complained about its lack of flexibility). See also Teitelbaum, J Am Society CLU \& ChFC 
phantom stock plans address this problem, however, by allowing employees to choose the date of settlement. ${ }^{45}$

\section{The Fiduciary Duties of Corporate Directors}

Directors must behave honorably toward those to whom they owe fiduciary duties. As one judge has noted, however, "while corporate directors do owe fiduciary duties, the duties are not owed to the world at large. ${ }^{\$ 46}$ This Section examines the different obligations directors owe to common stockholders, creditors, and phantom stockholders.

\section{A. Duties Owed to Common Stockholders}

A corporation's board of directors is responsible for managing the business affairs of the corporation. ${ }^{47}$ Directors review and approve significant investment and operational decisions, make financial decisions (such as whether to issue new securities or pay dividends), and appoint, monitor, and determine the compensation of the firm's officers. ${ }^{48}$ In this capacity, directors owe two specific duties to the corporation and its common shareholders: the duties of care and loyalty. ${ }^{49}$

First, the duty of care requires directors to exercise the care in their business affairs that a normally prudent person would exercise under similar circumstances. ${ }^{50}$ In order to comply with this duty, directors must review any and all material information before making a business decision. ${ }^{5 i}$ After reviewing all of the

at 47 (cited in note 1 ).

45 See note 18.

46 Ass'n of Haystack Property Owners, Inc. v Sprague, 494 A2d 122, 125 (Vt 1985).

47 Aronson $v$ Lewis, 473 A2d 805, 811 (Del 1984), quoting 8 Del Code Ann $\$ 141(a)$ (1991) ( ${ }^{*}$ The business and affairs of a corporation ... shall be managed by or under the direction of a board of directors ....").

49 See William A. Klein and John C. Coffee, Jr., Business Organization and Finance: Legal and Economic Principles 126-27 (Foundation, 5th ed 1993).

${ }^{49}$ Dennis J. Block, Nancy E. Barton, and Stephen A. Radin, The Business Judgment Rule: Fiduciary Duties of Corporate Directors 1 (Prentice Hall, 3d ed 1989). See also Aronson, $473 \mathrm{~A} 2 \mathrm{~d}$ at 811 (stating that directors owe certain fiduciary obligations to a corporation and its shareholders).

so See Norlin Corp. v Rooney, Pace Inc., 744 F2d 255, 264 (2d Cir 1984). See also Committee on Corporate Laws, Section of Corporation, Banking and Business Law of the American Bar Association, Corporate Director's Guidebook, 33 Bus Law 1591, 1600 (1978) ("TT]he corporate director [ ] assumes a duty to act carefully in fulfilling the important tasks of monitoring and directing the activities of corporate management.").

s1 See, for example, Smith v Van Gorkom, 488 A2d 858, 874 (Del 1985) (holding that directors breached their duty of care by hurriedly approving a merger without reading all of the relevant documents or considering alternatives). 
relevant information, the directors must act with "requisite care in the discharge of their duties." ${ }^{\prime 52}$ So long as directors perform these duties with reasonable prudence and do not breach their other fiduciary duties, they are free from liability.

Second, the duty of loyalty proscribes faithlessness and selfdealing by corporate directors and officers. ${ }^{53}$ When a director accepts his position, he "commits allegiance to the enterprise and acknowledges that the best interests of the corporation and its shareholders must prevail over any individual interest of his own.".54

Finally, courts apply the business judgment rule to determine whether directors have breached these fiduciary duties. ${ }^{55}$ This rule essentially directs courts to refrain from examining the business decisions nonconflicted directors or officers make. ${ }^{56}$ Consequently, the rule almost completely insulates directors from liability for actions taken while managing the corporation.

\section{B. Duties Owed to Creditors}

Corporate directors generally do not owe fiduciary duties to creditors or debt holders. ${ }^{57}$ Creditors have no existing property right or equitable interest to support these duties. ${ }^{58}$ The normal relationship between a corporation and its creditors is contractual rather than fiduciary in nature, and therefore, principles of contract law govern. ${ }^{59}$ Although modern contract law recognizes an implied covenant of good faith and fair dealing in all con-

${ }^{52}$ Aronson, 473 A2d at 812.

${ }^{53}$ Norlin, 744 F2d at 264.

54 Committee on Corporate Laws, 33 Bus Law at 1599 (cited in note 50).

55 Aronson, 473 A2d at 812. See also Block, Barton, and Radin, The Business Judgment Rule at $2-3$ (cited in note 49 ).

${ }^{65} \mathrm{~K}$ Klein and Coffee, Business Organization and Finance at 150 (cited in note 48). The business judgment rule applies where directors are: (1) making a business decision; (2) disinterested; (3) exercising due care; (4) acting in good faith; and (5) not abusing discretion or promoting waste. Block, Barton, and Radin, The Business Judgment Rule at 2 (cited in note 49).

57 See Simons $v$ Cogan, 549 A2d 300, 304 (Del 1988) (holding that a corporation and its directors have no fiduciary duty to holders of convertible debentures). See also Ass'n of Haystack Property Owners, Inc. v Sprague, 145 Vt 443, 494 A2d 122, 125 (1985).

${ }_{58}$ See Simons, 549 A2d at 304 ("Before a fiduciary duty arises, an existing property right or equitable interest supporting such a duty must exist.").

${ }^{59}$ See, for example, Katz $v$ Oak Industries Inc., 508 A2d 873, 879 n 7 (Del Chanc 1986) (holding that a director's decision to restructure long-term debt breached neither an express contractual duty nor the implied duty of good faith and fair dealing). 
tracts ${ }^{60}$ this implied covenant does not rise to the level of a fiduciary duty. ${ }^{61}$

The relationship between corporate directors and creditors changes, however, when a corporation becomes insolvent. In such a situation, the directors' fiduciary duties shift from the stockholders to the creditors, ${ }^{62}$ and the creditors become the equitable owners of the corporation. ${ }^{63}$ The directors and officers of an insolvent corporation are thus obligated to represent creditors instead of stockholders. ${ }^{64}$.

\section{Duties Owed to Phantom Stockholders}

No court has yet addressed whether corporate directors owe fiduciary duties to phantom stockholders; however, some courts have considered disputes involving phantom stock arrangements. In general, courts have analyzed these disputes from a contract perspective ${ }^{65}$ and have thus treated phantom stockholders more like creditors than common shareholders. ${ }^{66}$ Treating these agreements as contracts makes some sense: phantom shareholders own no equity in the firm, ${ }^{67}$ delegate no authority to management, and do not enlist management to act as their substitutes. ${ }^{68}$ Under such an analysis, phantom stockholders would

60 Id at 880. See also Restatement (Second) of Contracts § 205 (1979) (imposing "upon each party a duty of good faith and fair dealing in [the] performance and [ ] enforcement" of contracts).

61 Compare the description of fiduciary duties in note 4.

62 See, for example, In re STN Enterprises, 779 F2d 901, 904 (2d Cir 1985) ("The district court's ruling failed to take into account that, although in most states directors of a solvent corporation do not owe a fiduciary duty to creditors, quite the reverse is true when the corporation becomes insolvent."). See also Geyer $v$ Ingersoll Publications Co., 621 A2d 784, 787 (Del Chanc 1992) (holding that fiduciary duties to creditors arise when insolvency exists in fact, not merely upon the initiation of bankruptcy proceedings).

¿3 See Comment, Geyer v. Ingersoll Publications Co.: Insolvency Shifts Directors' Burden from Shareholders to Creditors, 19 Del J Corp L 177, 185 (1994). See also Steven R. Gross, Deborah F. Stiles, and Charles E. Joseph, Shifting Duties: Directors Face Risks in Workout, Natl L J 19, 19 (Apr 15, 1991).

64 See New York Credit Men's Adjustment Bureau, Inc. $v$ Weiss, 305 NY 1, 110 NE2d 397, 398 (1953) (holding that upon insolvency, directors are considered trustees for the benefit of the corporation's creditors).

65 See, for example, Healy $v$ Rich Products Corp., 981 F2d 68, 72 (2d Cir 1992) (interpreting the "no competition" clause of a phantom stockholder agreement as a contractual term).

${ }_{66}$ See, for example, Strzelecki v Schwarz Paper Co., 824 F Supp 821, 828 (N D Ill 1993) (holding that an employee alleging nonpayment under the phantom stock plan stated valid contract claims).

${ }_{67}$ See Teitelbaum, J Am Society CLU \& ChFC at 46 (cited in note 1); text accompanying note 31 .

${ }_{68}$ Unlike common stockholders, phantom stockholders make no capital investment in 
enjoy only traditional contractual rights. On the other hand, one can argue that phantom stockholders are much like minority shareholders in close corporations, to whom the majority does owe fiduciary duties: both groups often resemble partners, are involved in the day-to-day operation of the company, ${ }^{69}$ have no ready market for their shares, ${ }^{70}$ and are susceptible to potential abuses by the directors.

It is important to determine whether directors owe fiduciary duties to phantom stockholders because, like common stockholders, phantom stockholders may suffer when directors fail to act prudently in the management of the corporation-thus breaching their duty of care-or when they seek to maximize their own wealth at the expense of the corporation-a breach of their duty of loyalty. Furthermore, phantom stockholders may face problems associated with the valuation of the corporation and unfair trading by corporate insiders.

\section{Duty of care violations.}

The failure of directors to perform their duties with the care, skill, and prudence of "like persons in a like position" may endanger the interests of phantom stockholders. ${ }^{71}$ For example, assume that MicroPerfect, Inc., a large, cash-rich computer conglomerate, offers to purchase HighTech Industries. HighTech's board of directors hurriedly approves the sale without considering the possibility that there may be other proposals at higher prices. Moreover, the board neglects to read the reports provided by HighTech's officers and fails to seek expert advice. Because the directors did not adequately inform themselves, they have breached their duty of care. ${ }^{72}$ But because Hannah is not a common shareholder-as she would be had she bargained for shares of nonvoting common stock-she does not have standing to bring a derivative action against the directors for this breach. ${ }^{73}$

the corporation and, therefore, do not delegate authority to management. See text accompanying note 32 .

${ }_{6}$ See, for example, Spitz $v$ Berlin Industries, Inc., 1994 US Dist Lexis 1576, *1 (N D III); Healy v Rich Products Corp., 981 F2d 68, 69 (2d Cir 1992).

${ }^{30}$ See note 34.

${ }^{21}$ See Teitelbaum, J Am Society CLU \& ChFC at 47 (cited in note 1); Norlin Corp. $v$ Rooney, Pace Inc., 744 F2d 255, 264 (2d Cir 1984).

${ }_{72}$ Compare Smith $v$ Van Gorkom, 488 A2d 858, 874 (Del 1985).

${ }^{23}$ See Klein and Coffee, Business Organization and Finance at 196-97 (cited in note 48); Clark, Corporate Law $\$ 6.2 .1$ at 208 (cited in note 1). Compare Schilling $v$ Belcher, 582 F2d 995, 996 (5th Cir 1978) (" $[\mathrm{A}]$ shareholder who sells his stock pending appeal of a favorable judgment in a stockholder's derivative suit against the corporation, loses stand- 


\section{Duty of loyalty violations.}

Phantom stockholders also can be injured when directors breach the duty of loyalty by placing their own interests before those of the corporation. The most common duty of loyalty violation involves a self-dealing transaction, where a director causes the corporation to purchase property from him at an inflated price or to sell property to him at a bargain price. ${ }^{74}$ For example, consider a situation in which Harry Harrison, a director of HighTech, sells to the corporation a plot of land for a price far above its market value. If Harrison cannot show that this selfdealing transaction is inherently fair to HighTech, he will have breached the duty of loyalty. ${ }^{75}$ Again, since Hannah is not a common shareholder, she has no standing to bring a derivative suit and is left unprotected against this behavior.

\section{Valuation of the corporation.}

Another source of potential harm to phantom stockholders lies in the establishment of the corporation's value, the basis for determining the value of the employee's phantom stock. ${ }^{76}$ The danger is that officers and directors of the corporation may deliberately draw cash out of the company for the purpose of lowering the value of the phantom stock. ${ }^{77}$ While this problem may rightly be considered another form of director self-dealing, it is worth examining more specifically in this context because accurate valuation of the corporation is vital to protecting the interests of phantom stockholders.

Assume, for example, that Hannah has worked at HighTech Industries for nearly ten years and that almost all of the one thousand shares with which she was originally credited in the phantom stock agreement have vested. Realizing that the company will owe a substantial amount of cash to Hannah when she settles her phantom stock account, the Harrison family, as the board of directors of HighTech, decides to draw out large

\footnotetext{
ing to further prosecute or defend the case ....").

${ }_{74}$ Duty of loyalty violations may also occur in situations where directors usurp business opportunities from the corporation, compete unfairly with it, or improperly resist a corporate takeover in order to maintain their own control. See Klein and Coffee, Business Organization and Finance at $166-69$ (cited in note 48 ).

75 Id at 163-64.

${ }^{76}$ See Teitelbaum, J Am Society CLU \& ChFC at 47 (cited in note 1). See also text accompanying notes $20-23$.

${ }^{77}$ See Teitelbaum, J Am Society CLU \& ChFC at 47 (cited in note 1).
} 
amounts of cash from the business as salary, thereby reducing the value of the corporation. By this self-dealing the Harrisons have breached the fiduciary duty of loyalty. Their actions injure Hannah because the value of her phantom stock account is based on the (now deflated) value of HighTech Industries and, without fiduciary protections, she has no standing to sue.

\section{Unfair trading by corporate insiders.}

Insider trading by corporate directors also can injure phantom stockholders. Assume again that Hannah has been employed at HighTech for a number of years, so that nearly all of her originally credited phantom shares have vested, but that she is now contemplating leaving the company for other career opportunities. Just as Hannah is considering cashing out her phantom stock account and departing for greener pastures, MicroPerfect approaches Harry Harrison and offers to purchase HighTech Industries for a price significantly in excess of HighTech's present value. Harry talks to his family (the common shareholders), and they decide to sell HighTech to MicroPerfect in order to take advantage of the opportunity that has suddenly become available. Because Hannah, as a phantom stockholder, is in the position of a mere debt holder, Harry is not required to disclose to her the inside information about the impending purchase. ${ }^{78}$ As a result, Hannah is likely to settle her account before the purchase occurs and miss out on the substantial profits she would have gained had she retained her phantom stock.

\section{The RELATIONSHIP BETWEen CoRporate DiRectors AND PHANTOM STOCKHOLDERS}

The previous Sections examined the characteristics of phantom stock and the fiduciary duties of corporate directors, and raised the question of whether directors should owe fiduciary duties to phantom stockholders. This Section answers that ques-

${ }^{78}$ See Clark, Corporate Law $\$ 6.2 .1$ at 208-09 (cited in note 1) (insider trading rules do not apply to phantom stock plans). But see Jordan $v$ Duff and Phelps, Inc., 815 F2d 429 (7th Cir 1987), where a divided panel held that under Securities Exchange Act Rule 10b-5, a corporation contemplating a lucrative merger had a duty to volunteer information about the merger to a stockholder-employee who was considering quitting his job and selling his stock back to the company, as required by the stockholder agreement. Judge Easterbrook's discussion of this duty, however, is premised on the fact that the employee was a holder of common stock and was owed other fiduciary duties. See id at 435 . It is unlikely that corporate directors would be required to disclose an impending merger to debt holders or creditors. 
tion in the negative, concluding that, in order to protect the bargained-for contracts between phantom stockholders and corporations, courts should refuse to recognize a fiduciary duty running from directors to holders of phantom stock.

\section{A. Contract Law versus Corporate Law}

Contract law, and its implied contractual duties of good faith and fair dealing, should determine the protections phantom stockholders receive from the actions of corporate directors. If phantom stock does not carry fiduciary duties, employees possess greater freedom to select compensation programs that fit their particular needs and desires. Employees can choose either to receive the benefits of fiduciary protections by bargaining for nonvoting common stock, or to forego those benefits by seeking a phantom stock arrangement. It makes little sense, therefore, to argue that fiduciary duties should trump actual, bargained-for phantom stockholder agreements. Extending fiduciary duties to holders of phantom stock would serve only to eliminate the distinction between nonvoting stock and phantom stock, thereby depriving the parties of a contracting option. Since the fiduciary duties of corporate law serve to complete imperfect bargains in a contractual setting, ${ }^{79}$ corporate directors should not owe fiduciary duties to phantom stockholders. ${ }^{80}$

Suppose, for example, that Hannah is negotiating an employment contract with HighTech Industries. HighTech proposes to include in her total compensation package an incentive-based, deferred compensation plan. Two possible plans are contemplated: a phantom stock arrangement and a nonvoting common stock arrangement. Hannah wants a plan that will give her ownership of HighTech nonvoting stock and place her in a fiduciary relationship with HighTech's directors. She believes that a nonvoting common stock arrangement is less risky than a phantom stock plan. The directors, however, want to avoid assuming fiduciary duties toward Hannah. In the final contract between the parties, Hannah accepts a phantom stock arrangement and, in consideration, is credited with fifty more shares of HighTech phantom stock than she was initially offered. Consequently, the riskiness

79 See Frank H. Easterbrook and Daniel R. Fischel, The Economic Structure of Corporate Law 92-93 (Harvard, 1991).

${ }_{80}$ Compare William W. Bratton, Jr., The Economics and Jurisprudence of Convertible Bonds, 1984 Wis L Rev 667, 730-39 (arguing that corporate directors should not owe fiduciary duties to bondholders). 
of the phantom stockholder agreement-and the cost of the fiduciary duties-is reflected in the "price" of the phantom shares and in the structure of the resulting agreement.

In such a situation, the contractual terms of the phantom stockholder agreement, rather than fiduciary principles, should control. First, both employers and employees will benefit. Employers will be able to extend phantom stock to employees without taking on additional fiduciary duties, and employees will have the option of either bargaining for fiduciary protections or receiving extra compensation for accepting phantom stock without such protections. Where directors have engaged in self-dealing to undervalue the corporation or traded unfairly on inside information, the extra compensation employees receive for accepting phantom stock reflects, in some measure, the ex ante probability that such director misbehavior might actually occur. Injured employees are thus compensated for the risk.

Second, respecting the terms of the bargained-for agreement promotes efficiency. When left to bargain freely, parties with full information about the choice between fiduciary-governed nonvoting stock and contract-governed phantom stock can efficiently determine the value of fiduciary protections. Highly sought after employees (either for recruitment or retention) are likely to be sophisticated bargainers with adequate information, as companies will compete for their services by offering various employment alternatives. If the option to bargain for fiduciary-free phantom stock is removed, these parties will not necessarily adopt only fiduciary-governed deferred compensation plans: they are more likely to explore other, less desirable options as well. For example, it is not clear that if HighTech Industries was precluded from offering Hannah fiduciary-free phantom stock the company would offer her nonvoting common stock with fiduciary protections. In order to avoid such obligations toward Hannah, HighTech might instead pursue less efficient options, such as increasing her salary or failing to retain her. Increasing Hannah's salary may be less efficient (or impossible) if HighTech is trying to reserve capital for other purposes. Similarly, failing to retain Hannah-a real possibility if HighTech cannot issue her fiduciary-free phantom stock or is unable to raise her salary-is less efficient because HighTech will presumably be forced to hire and train a replacement. 
It is true that fiduciary duties can sometimes be an efficient substitute for costly contracts. ${ }^{81}$ Some commentators have argued that corporate law is efficient if it provides standard, implied contract terms that give creditors the sort of protections against default for which they normally would contract. ${ }^{82}$ Thus, if Hannah and HighTech negotiated the terms of her phantom stockholder agreement absent a background of fiduciary law, the parties would have to include specific terms about the duty of care HighTech's directors would assume toward Hannah, the directors' willingness to avoid self-dealing, and so forth. Such negotiations, it is argued, are less efficient than the imposition of corporate fiduciary duties.

Extending fiduciary duty law to the relationship between corporate directors and phantom stockholders, however, would be more costly and less efficient than simply allowing the parties to bargain for fiduciary duties according to the type of compensation plan they choose. With this freedom, for example, Hannah need not inefficiently bargain for each and every fiduciary protection and translate them to contract terms. Instead, she can simply bargain for nonvoting common stock if she wants fiduciary protections, or for phantom stock if she does not. ${ }^{83}$ The flexibility to exercise such contracting options will ultimately be limited if phantom stockholders are allowed to receive the protection of fiduciary duties for which they have not bargained; corporations will simply decline to "issue" such costly phantom stock.

Third, in a contract setting, parties dealing at arm's length can bargain hard and enforce their deals to the letter, no matter how severe the consequences to the other side. ${ }^{84}$ With phantom stock agreements in particular, there is little reason to fear that employees entering into such arrangements are less sophisticated or have less bargaining power than employers. By definition, a "key" employee to whom phantom stock has been offered is bargaining from a position of strength-the employer needs the

81 See Daniel R. Fischel, The Corporate Governance Movement, 35 Vand L Rev 1259, 1264 (1982).

82 See Easterbrook and Fischel, The Economic Structure of Corporate Law at 34 (cited in note 79). See also Richard A. Posner, The Rights of Creditors of Affiliated Corporations, 43 U Chi L Rev 499, 506-09 (1976).

83 Theoretically, if phantom stock is not accompanied by director fiduciary duties it will be less expensive than nonvoting equity stock.

84 Easterbrook and Fischel, The Economic Structure of Corporate Law at 90 (cited in note 79 ). 
employee and is trying to recruit or retain him. Consequently, the employee may request nonvoting common stock, bargain for fiduciary-like protections in the phantom stockholder agreement, or negotiate for additional consideration in exchange for assuming the risks associated with phantom stock.

Fourth, corporations enter into contracts with many parties, including suppliers, workers, and bondholders. Because contracts with these parties can be written in detail, the rights of these parties vis-à-vis the corporation can be specified and there is no need for fiduciary duties. ${ }^{85}$ Both workers (through employment contracts) and bondholders (through bondholder agreements) are protected by the terms of their contracts, rather than by fiduciary duties. ${ }^{86}$ Similarly, where workers are also phantom stockholders, both their rights in employment and their "investment" rights under the phantom stockholder agreement can be written specifically enough to eliminate the need for fiduciary duties. Phantom stockholders, like bondholders, can be protected against duty of care and duty of loyalty violations by the specific terms of the phantom stockholder agreements. Moreover, as with bonds, the risk that directors will abuse their power and harm phantom stockholders will be reflected in the stock's "price," a term of the phantom stock contract.

As previously discussed, the similarities between phantom stock and nonvoting common stock support the conclusion that the bargain of the parties should govern. ${ }^{87}$ It is precisely because they are so similar that courts should respect the decision by employers and employees specifically to enter into either phantom stockholder or nonvoting common stockholder agreements. Employees desiring fiduciary protection can negotiate for nonvoting common stock, while employers attempting to avoid fiduciary responsibilities can choose to offer only phantom stock. Thus, the similarity of these two deferred compensation options strengthens the argument that the option ultimately selected, in its originally bargained-for form, should control the relationship of the parties.

Finally, there are some situations where parties may not bargain around fiduciary duties. The Employee Retirement In-

ss Id at 90-91.

is See, for example, Broad $v$ Rockwell Intl. Corp., 642 F2d 929, 955-60 (5th Cir 1981) (en banc) (stating that managers' fiduciary duties to bondholders need not be analyzed where those obligations are exceeded by contractual duties).

${ }^{87}$ See text accompanying notes 26-29. 
come Security Act of 1974 ("ERISA"), for example, prohibits parties from such bargaining in the context of retirement income. ${ }^{88}$ The legislative history of ERISA, however, suggests that Congress did not intend for this prohibition to extend to phantom stock. ${ }^{89}$ Congress's decision not to extend the prohibition again supports the argument that the bargained-for terms of the phantom stockholder agreement should be preferred over fiduciary rules.

\section{B. Problems with Extending Fiduciary Duties to Phantom Stockholders}

There are several problems with extending fiduciary duties to phantom stockholders, rather than respecting their bargainedfor contracts. First, phantom stockholders will be overprotected if the terms of the phantom stockholder agreement do not control. Second, officers and directors will be hindered in their efforts to effectively manage the corporation because they will owe fiduciary duties to two different and sometimes conflicting constituencies.

\section{Overprotection of phantom stockholders.}

Corporate fiduciary law is undesirable in the context of phantom stock plans because fiduciary principles will necessarily override express contractual provisions in the phantom stockholder agreements and create the risk of overprotecting phantom stockholders. ${ }^{90}$ Overprotection is costly, and corporations (and

8s See 29 USC $\S 1104$ (1988 \& Supp 1993).

69 One court has held that ERISA may govern some phantom stock arrangements. See note 17. It appears, however, that Congress did not intend for the fiduciary requirements of ERISA to extend to phantom stock plans. The Conference Report in the legislative history of ERISA states:

[T] he labor fiduciary rules do not apply to [a] . . . plan primarily devoted to providing deferred compensation for a select group of management or highly compensated employees. For example, if a "phantom stock" or "shadow stock" plan were to be established solely for the officers of a corporation, it would not be covered by the labor fiduciary rules.

Employee Retirement Income Security Act of 1974, Conference Report, HR Rep No 931280, 93d Cong, 2d Sess 296 (1974). In passing ERISA, Congress may have declined to extend the fiduciary duties of corporate directors to phantom stockholders under the assumption that most phantom stockholders would be either officers or directors. In such a situation, requiring corporate officers and directors to owe fiduciary duties to themselves as phantom stockholders would be superfluous. But even if lower-level employees were granted phantom stock, placing them in a fiduciary relationship with directors would be imprudent for the reasons outlined in this Section.

90 Compare Bratton, 1984 Wis L Rev at 739 (cited in note 80 ) (arguing that extending 
consequently their shareholders) will be the parties who bear this cost.

Assume that Hannah agrees to receive in her compensation package phantom stock, rather than nonvoting common stock, after HighTech offers her a greater number of phantom shares as consideration for accepting a fiduciary-free arrangement. If, in a later judicial proceeding, fiduciary duties toward Hannah are imposed on HighTech's directors, Hannah will have been overprotected. In essence, she will have received more than she bargained for-both a greater number of phantom shares and the fiduciary protections that typically accompany common stock. HighTech, on the other hand, will be forced to bear the costs of both the bargain (granting the extra shares to Hannah) and the judicial imposition of fiduciary duties. ${ }^{91}$ Such a result is far less satisfactory than that which would be reached by simply allowing the parties to bargain for fiduciary protections.

\section{Corporate governance problems.}

Another potential problem with extending fiduciary duties to phantom stockholders is that directors cannot fully serve both equity and phantom stockholders simultaneously. Management would be subject to conflicting obligations if it had a duty both to maximize stockholder returns and to protect the interests of phantom stockholders. ${ }^{92}$

For example, assume that Hannah's phantom stockholder agreement with HighTech Industries is structured so that it does not pay her the equivalent of the dividends paid on the underlying stock. The Harrisons, as directors, vote to pay out large dividends to the shareholders, themselves. This action decreases the value of HighTech at the expense of Hannah, whose phantom stock account is valued in direct relation to the value of the company.

In this situation, HighTech's directors face a dilemma if they owe fiduciary duties both to HighTech's common stockholders and

fiduciary duties to bondholders will result in overprotection of them).

91 The uncertainty of the law as to whether directors owe phantom stockholders fiduciary duties, coupled with the fact that no jurisdictions has yet addressed this issue, strongly indicates that such overprotection would not be a one-time problem, but would recur repeatedly from one jurisdiction to the next.

$\$ 2$ Compare John C. Coffee, Jr., and Donald E. Schwartz, The Survival of the Derivative Suit: An Evaluation and a Proposal for Legislative Reform, 81 Colum L Rev 261, 313 (1981) ("[T] interests of equity holders and those of creditors frequently conflict, and the board cannot serve both equally in making determinations about business risks."). 
to Hannah, a phantom stockholder. Because they owe a duty to Hannah to protect the value of her phantom stock account and to the common shareholders to pay out dividends, the business judgment rule would not insulate the directors from liability for their determination of dividend payments. Instead, the directors would have to show that every dividend decision (and possibly every corporate decision) they made was appropriate. Such a result is substantially less efficient than a finding that the directors do not owe fiduciary duties to phantom stockholders, as the business judgment rule operates to promote efficiency by allowing directors to make business decisions freely.

To protect herself from such a situation, Hannah could bargain for assurances that the payment of dividends would be reasonable. Alternatively, she could bargain for more shares of phantom stock in return for assuming the risk that directors might attempt to reduce the value of the company by paying out excessive dividends.

Admittedly, corporate directors already must resolve conflicts between security holders. The clash of interests between preferred and common stockholders, for example, can be similar to the conflict between equity and phantom stockholders. ${ }^{93}$ Despite the conflict, directors owe a fiduciary duty to both classes of stockholders. ${ }^{94}$ But just as the allocation of dividends between preferred stockholders and common stockholders is controlled by the contractual provisions of the individual stockholder agreements, so too should the contract provisions in the phantom stockholder agreement prevail where phantom stock is concerned. ${ }^{95}$

\section{Phantom Stockholders versus Common Stockholders}

Although some commentators have noted that common stockholders are no more the owners of a company than are creditors or employees, ${ }^{96}$ it is certain that courts do not consider phantom stockholders to be a corporation's owners. ${ }^{97}$ Unlike common

93 Compare Ronald J. Gilson, The Case Against Shark Repellent Amendments: Structural Limitations on the Enabling Concept, 34 Stan L Rev 775, 834-36 n 229 (1982) (asserting that in some situations the conflict between two classes of stock is the same as the conflict between common stockholders and bondholders).

${ }^{94}$ See note 28.

95 See Section III.A.

${ }_{96}$ Frank H. Easterbrook and Daniel R. Fischel, Voting in Corporate Law, 26 J L \& Econ 395, 396 (1983). See also Easterbrook and Fischel, The Economic Structure of Corporate Law at 24-25 (cited in note 79).

${ }_{97}$ Teitelbaum, J Am Society CLU \& ChFC at 46 (cited in note 1) ("[P]hantom stock 
stockholders, phantom stockholders neither invest capital in the corporation $^{98}$ nor delegate authority to the directors. ${ }^{99}$ Consequently, phantom stockholders have no ownership interest in the corporation.

Proponents of extending director fiduciary duties to phantom stockholders contend that phantom stockholders are like minority shareholders in close corporations. ${ }^{100}$ There is often very little difference, in close corporations, between the relationship of the directors to phantom stockholders and the relationship of the directors to common stockholders. Furthermore, majority shareholders in close corporations owe a high standard of fiduciary duty to minority shareholders. ${ }^{101}$ Thus, proponents of extending fiduciary duties to phantom stockholders may argue that since phantom stockholders (in corporations generally) are like minority shareholders in close corporations, phantom stockholders should receive fiduciary protections.

Phantom stockholders do resemble minority shareholders in close corporations in several respects. For example, phantom stockholders often participate in the operation of the corporation, ${ }^{102}$ and they have no ready market for their shares. ${ }^{103}$

plans are ideal for businesses that wish to provide compensation to employees without relinquishing equity interests."); Hutchings, J Am Society CLU at 34 (cited in note 1).

${ }^{98}$ Advocates of extending fiduciary duties to phantom stockholders may argue that employees who accept phantom stock as a part of their total compensation effectively "invest" in the firm. For example, assume Hannah is offered a one-year contract at MicroPerfect with a salary of $\$ 100,000$. In response, HighTech offers her a one-year contract with a salary of $\$ 90,000$ plus $\$ 10,000$ worth of phantom stock, which Hannah accepts. One might argue that by foregoing the extra $\$ 10,000$ in salary and instead accepting $\$ 10,000$ worth of HighTech phantom stock, Hannah has invested in the firm. However, since Hannah did not bargain for fiduciary duties, her "investment" is more like the investment of a bondholder (to whom no fiduciary duties are owed) than that of a common stockholder.

99 See note 68 .

100 One court has defined close corporations as having a small number of shareholders, significant shareholder participation in the operation of the corporation, and no ready market for shares. Donahue v Rodd Electrotype Co. of New England, Inc., 367 Mass 578, 328 NE2d 505, 511 (1975).

${ }^{101}$ See id at 515 (holding that "strict" fiduciary duties exist for all close corporation shareholders because of the similarity between close corporations and partnerships). See also Crosby v Beam, 47 Ohio St 3d 105, 548 NE2d 217, 221 (1989) (holding that majority or controlling shareholders in a close corporation have a heightened fiduciary duty to minority shareholders).

102 Phantom stockholders, because they are typically highly-valued, key employees, often participate in the operation of the business. See, for example, Spitz $v$ Berlin Industries, Inc., 1994 US Dist LEXIS 1576, *1 (N D Ill). See also Healy v Rich Products Corp., $981 \mathrm{~F} 2 \mathrm{~d}$ 68, 69 (2d Cir 1992).

Minority stockholders in close corporations often engage in similar behavior. Unlike most stockholders in public corporations, who are simply seeking a return on their invest- 
Moreover, advocates would argue, phantom stockholders are susceptible to the same dangers that inherently affect minority shareholders in close corporations. ${ }^{104}$

The similarities between phantom stockholders and minority shareholders in close corporations, however, are not strong enough to overcome the fact that phantom stockholders neither invest in corporations nor delegate authority to directors in the same way that common shareholders do. Furthermore, courts should be little concerned for the welfare of phantom stockholders. First, phantom stockholders in large, publicly held corporations are for the most part protected from director abuse by the fiduciary duties running from the directors to the common shareholders. Because the shares of the common stockholders underlie the phantom shares, ${ }^{105}$ there is little danger of director abuse. If directors fulfill their fiduciary duties to the common shareholders and maximize the value of the corporation, the phantom shareholders will be protected. More importantly, however, employees offered phantom stock have the option of bargaining instead for nonvoting common stock, virtually identical to phantom stock except that it carries fiduciary protections.

Second, even in close corporations there is insufficient reason to be concerned with the possibility that directors might take advantage of phantom stockholders. ${ }^{106}$ As with phantom stockholders in large corporations, employees are still free to bargain for nonvoting common stock with fiduciary protections, instead of accepting phantom stock without such protections.

ment and often have only a passive interest in the day-to-day operation of the business, stockholders in close corporations typically take an active role in the operation of the company. See F.H. O'Neal and R. Thompson, 1 O'Neal's Oppression of Minority Shareholders § 3:06 at 37 (Clark Boardman Callaghan, 2d ed 1994).

${ }^{103}$ Phantom stock is typically illiquid. In fact, many phantom stock agreements stipulate that the phantom stock granted to the employee is inalienable. See text accompanying note 34 .

Stock in close corporations is usually unmarketable as well. While a disgruntled minority shareholder in a publicly held corporation can easily sell his stock, it is just the reverse for minority shareholders in a close corporation. See O'Neal and Thompson, 1 O'Neal's Oppression of Minority Shareholders § 3:06 at 37.

${ }_{104}$ Minority shareholders in close corporations, for example, may be especially susceptible to problems associated with valuation of the corporation and insider trading. See text accompanying notes 76-78.

${ }^{105}$ See text accompanying notes 20-23.

${ }_{106}$ This remains true even though in the typical close corporation there are few common shareholders, the common shareholders are usually also corporate insiders, and, consequently, employees receiving phantom stock may be more susceptible to harm. 
Moreover, phantom stockholders are more similar to creditors than they are to minority shareholders in close corporations. Because phantom stock is a contractual right to "a deferred cash bonus," phantom stockholders are essentially creditors. ${ }^{107}$ In all corporations, common stockholders receive fiduciary protections because, as owners, they delegate responsibility for the management of the corporation to the directors. In return, directors promise, through fiduciary duties, to work hard and honestly. ${ }^{108}$ In contrast, the considerations of trust, agency, and delegation of power that underlie duties to stockholders are not involved where creditors are concerned. Since phantom stockholders are like creditors, phantom stock should not carry with it the rights enjoyed by common shareholders, such as the rights to vote, inspect, and sue derivatively ${ }^{109}$-nor should directors owe phantom stockholders fiduciary duties.

\section{CONCLUSION}

Courts should refuse to recognize fiduciary duties running from corporate directors to holders of phantom stock. Contract law should prevail over corporate fiduciary law in the context of phantom stockholder agreements because employees in this situation typically have both equal bargaining power and the opportunity to negotiate for fiduciary duties by bargaining for nonvoting common stock. Conversely, if fiduciary duties were extended to phantom stockholders, overprotection of phantom stockholders and problems of corporate governance would likely result. Finally, phantom stockholders are not sufficiently similar to minority shareholders in close corporations to merit the same fiduciary treatment or to enjoy the security that accompanies fiduciary relationships.

107 See Clark, Corporate Law $\$ 6.2 .1$ at 208 (cited in note 1).

${ }^{108}$ Easterbrook and Fischel, The Economic Structure of Corporate Law at 91 (cited in note 79).

${ }_{109}$ See Clark, Corporate Law $\S 6.2 .1$ at 208 (cited in note 1). 
. 